\title{
Constricting restricted transcription: the (actively?) shrinking web
}

\author{
Peter Fraser $^{1}$ and James Douglas Engel ${ }^{2,3}$ \\ ${ }^{1}$ Laboratory of Chromatin and Gene Expression, The Babraham Institute, Babraham Research Campus, Cambridge CB2 4AT \\ United Kingdom; ${ }^{2}$ Department of Cell and Developmental Biology, University of Michigan Medical School, \\ Ann Arbor, Michigan 48109-2200, USA
}

It is now quite generally accepted that the mammalian genome is, in essence, littered with functionally critical regulatory elements that can be located anywhere in relationship to the gene that they control: internally, $5^{\prime}$ or $3^{\prime}$, sometimes even more than a megabase away (Lettice et al. 2002). Furthermore, seemingly straightforward activities of a gene can be controlled by multiple spatially or temporally distinct enhancers, even for eliciting, in a single developing tissue, functions that never could have been identified as distinct by conventional methods (Khandekar et al. 2004). The discovery and initial exploration of the activity of globin gene enhancers has served as a well-documented paradigm for how such activities are mechanistically interpreted. Following discovery of the delocalized $\beta$-type globin gene enhancers (that later became known as the locus control region, the LCR), decades of experiment and speculation followed /Choi and Engel 1988; Enver et al. 1990; Tuan et al. 1992; Wijgerde et al. 1995; Martin et al. 1996; Bulger and Groudine 1999/ that addressed the mechanisms underlying enhancer/LCR function. The mechanism of long-range enhancer function was at least partially resolved in 2002, thereby ending (at least one aspect of) this ancient debate. Using novel techniques capable of measuring the spatial proximity of distal genomic elements it was shown that the LCR and actively transcribed globin genes were in close physical proximity inside erythroid cells, looping out the sequences lying between the LCR and globin gene promoter (Carter et al. 2002; Tolhuis et al. 2002). The results strongly implied that a direct functional interaction between the LCR and globin gene was necessary for high-level transcription. A report in this issue of Genes \& Development by Ragoczy et al. (2006) now shows that the LCR directs the nuclear relocation of the globin locus during erythroid differentiation and directs its colocalization to specific nuclear subcomponents, providing further insight into the mechanisms of long-range transcriptional regulation and LCR function.

${ }^{3}$ Corresponding author.

E-MAIL engel@umich.edu; FAX (734) 763-1166.

Article is online at http://www.genesdev.org/cgi/doi/10.1101/gad.1438106.
Inside the nucleus

The fact that nuclear compartmentalization exists has been known since the dawn of light microscopy, but the less appreciated possibility that subnuclear organization might functionally contribute to the control over the transmission of genetic information can equally no longer be in doubt. While it has long been appreciated that the nucleus has a visible, dynamic substructure and can be remarkably heterogeneous with regard to the appearance of chromatin structures from different environmental conditions, differentiation states, or different cell types of origin, what has often been missing from experiments that address nuclear structure is a clear indication of whether this organization is the cause or consequence of gene function.

In recent years we have glimpsed the first indications that point to the prospect that in at least some cases genes migrate to specific subnuclear compartments to execute transcription, while in other cases it appears that compartmentalization is more likely to be a consequence of gene activity. What is becoming clear is that many molecular events and mechanisms are intimately integrated into a highly choreographed pathway that lead to the efficient and heritable activation or repression of a given gene. Identification of the major players and understanding their roles in this three-dimensional pavane remains a major challenge in deciphering the cryptic code that controls our genome as well as in understanding its complex translation into function.

\section{Inside vs. way inside}

The dynamic repositioning of genes within the nucleus during development and differentiation is nonrandom, and often correlates with gene expression status. Gene colocalization with constitutive heterochromatin or the nuclear periphery is usually associated with silencing (Brown et al. 1997, 1999; Andrulis et al. 1998), whereas a more gene-internal nuclear localization has been generally associated with actual or potential transcriptional activity (Francastel et al. 1999; Kosak et al. 2002). The relationship of a gene to its chromosome territory is also 
highly correlated with expression. Active genes have been seen to extend considerable distances outside their chromosome territories (Cremer and Cremer 2001), whereas inactive genes, in general, tend to remain within or at the surface of their territory (Mahy et al. 2002a,b; Chambeyron and Bickmore 2004). Although only a limited number of cases have been examined in sufficient detail, it is tempting to speculate from these few examples that these subnuclear locations dictate the activity state or epigenetic signature of the genes that enter them. Indeed, a common notion with some support is (for example) that the nuclear periphery is a functionally repressive compartment, actively altering the epigenetic state of genes that are addressed to that compartment to heritably silence gene expression (for review, see Hetzer et al. 2005). However, there are also counterexamples to contradict this generalization. For example, the IFN $\gamma$ gene is located in the extreme nuclear periphery in immature, naive $\mathrm{T}$ helper cells, and remains peripheral regardless of whether those cells differentiate along the Th2 pathway (in which case the IFNy locus remains silent) or resolve to a Th1 fate wherein high levels of IFNy are expressed (Hewitt et al. 2004).

Ragoczy et al. (2006) now clearly demonstrate that the nuclear periphery is not necessarily repressive; they show that the mouse $\beta$-globin locus is largely positioned in the nuclear periphery in erythroid progenitor cells prior to the most abundant phase of globin gene transcriptional activation. $\beta$-Globin transcription begins while the locus is still clearly in the periphery, and only later migrates to a more interior location as erythroid cells differentiate. So, even though a prominent role may exist for silencing compartments in the nuclear periphery, it is clear in both cases cited here that activation can occur there as well. So why does the globin locus move to a more internal location if transcription can occur at the periphery?

\section{Migration by remote control?}

Ragoczy et al. (2006) address the question of nuclear position versus transcriptional status by charting the course of the $\beta$-globin locus during erythroid maturation. After purification of staged progenitors from both wild-type and LCR-deleted mouse strains, precursor cells representing the various stages of erythroid differentiation were monitored by FISH and immunolocalization. Without the LCR, the locus departs the periphery later during differentiation than does the wild-type locus, and never fully traverses the course of the wild-type locus into the interior of the nucleus. These results imply that placement (or timing of repositioning) is important, and suggest that the LCR directly or indirectly affects the nuclear address of the globin locus. But how does it do this, and why should intranuclear position matter?

The LCR was originally defined in transgenic assays as a complex element that was capable of conferring position-independent, copy number-dependent expression to linked transgenes (Grosveld et al. 1987). These properties led to the suggestion that the LCR was responsible for opening an erythroid-specific chromatin domain as a (possibly critical) initial step in activating the entire locus. However, examination of the endogenous murine locus later showed that the LCR was not required, either for an open chromatin structure or an active histone modification profile across the whole locus (Bender et al. 2000; Schubeler et al. 2001), implying that other sequence elements within or nearby controlled these functions (Gribnau et al. 2000). In those studies, deletion of the LCR did profoundly affect globin gene expression levels, suggesting that the primary function of the LCR is to act as a powerful long-range enhancer. Ragoczy et al. (2006) now show (using RNA FISH) that the drastically diminished expression of the adult $\beta$-globin gene in the LCR-deleted mouse strain is due to the fact that only a minority of the globin genes are transcribed at any given time. Furthermore, by using DNA FISH and immunological detection of hyperphosphorylated RNA polymerase II, they find that only a fraction of the LCRdeleted loci colocalize with active RNA polymerase II foci, also known as "transcription factories" (Fig. 1). Previous reports have shown that transcription factory subnuclear foci are sites of nascent gene transcription that are highly enriched in the active, hyperphosphorylated form of RNA polymerase II (Jackson et al. 1993; Wansink et al. 1993; Iborra et al. 1996; Grande et al. 1997), and importantly, each factory potentially contains multiple, actively transcribed genes (Jackson et al. 1998; Osborne et al. 2004). Normally, nearly every globin locus in a population of transcriptionally active erythroid cells is in contact with a transcription factory, and therefore displays a primary transcript RNA FISH signal, implying almost continuous globin gene transcription /Osborne et al. 2004). However, for other genes that are less abundantly transcribed than globin (i.e., everything else in an erythroid cell) only a minority of alleles colocalize with factories, strongly correlating with their less frequent transcription and lower expression. Ragoczy et al. (2006) show that in erythroid cells that lack the LCR, the globin genes now behave like these other more moderately expressed genes: They adopt a configuration in which they are less frequently engaged with active transcription factories and thus less frequently transcribed. One thus reaches the inescapable conclusion that some property conferred by the LCR must be responsible for homing to active factories.

These observations raise central questions regarding the nature of transcription factories, the topology of LCR-gene-nuclear substructure complexes, and the relationships between them. Work conducted more than two decades ago suggested that transcription factories are relatively stable aggregations of RNA polymerase II attached to some sort of nuclear substructure, or skeleton (Jackson and Cook 1985; Jackson et al. 1993). More recent work indicates that individual factory components are continually exchanged (Kimura et al. 2002), suggesting that transcription factories are dynamic selforganizing (Misteli 2001) collectives of transcriptional components that are comparatively fixed in space. 


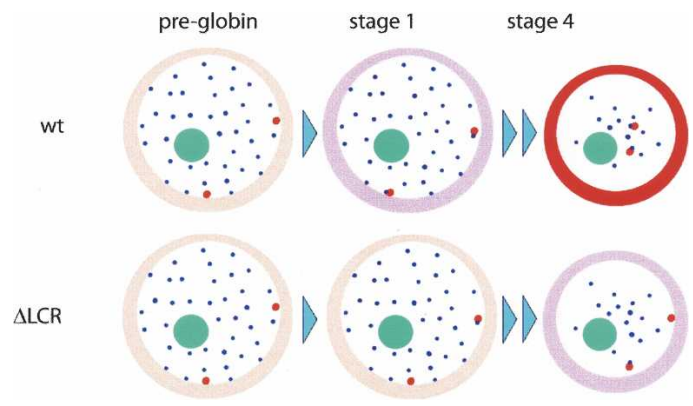

Figure 1. Role of the LCR in nuclear organization of the $\beta$-globin genes during erythroid differentiation. A schematic summary of the changes in nuclear position of the murine $\beta$-globin genes (red dots) and their relationship to transcription factories (black dots). In wild-type erythroid cells prior to abundant globin expression, the $\beta$-globin genes are found in the nuclear periphery and are not associated with transcription factories. Globin gene expression (pink cytoplasm) begins in stage 1 of differentiation when the genes colocalize with transcription factories (Ragoczy et al. 2006). At differentiation stage 4, factory numbers are reduced and redistributed toward the nuclear interior. Globin gene expression is high (red cytoplasm) and globin loci are found predominantly in the nuclear interior in association with transcription factories. (Bottom panel) In the LCR knockout erythroid progenitors, $\beta$-globin gene association with transcription factories is incomplete or intermittent, resulting in uniform, but diminished, $\beta$-globin expression in all erythroid cells. In stage 4 cells of the LCR deletion mutants, a significant number of globin alleles remain in the periphery, and only a small fraction are coincident with transcription factories.

\section{Greener pastures, or roll your own?}

While current work leaves open the answers to many remaining questions, there are clues that provide some interesting suggestions. Ragoczy et al. (2006) show that RNA polymerase II factories are redistributed during erythroid maturation (Fig. 1). In early erythroid progenitors, factories are greater in number and relatively evenly distributed between the nuclear interior and periphery. In the most mature erythroid progenitor cells, factory numbers are reduced and redistributed toward the nuclear interior with a noticeable decrease in the periphery. It is possible that the globin locus and hundreds of other coexpressed genes are drawn toward the nuclear interior in pursuit of increasingly scarce transcriptional machinery. This type of model (Fig. 2A) implies that the redistribution of the factories plays a decisive role in the reorganization of the nucleus during differentiation (Chakalova et al. 2005). Globin loci that are missing the LCR, and therefore cannot form a stable association with a factory, would be left behind during this migration, interacting only intermittently and unstably with the few factories remaining in the periphery. Conversely, the LCR and the factors that bind to it may confer some sort of directionality that result in a relocation of the locus to the nuclear interior. In this scenario (Fig. 2B), other active genes would also require elements or marks that direct them to interior nuclear locations. Chromatin structure and histone modifications would be an obvious choice owing to the visible segregation of eu- and het- erochromatin under the light microscope, but chromatin structure and histone modifications are both relatively unperturbed in the LCR mutant locus with the exception of the promoter hypersensitive sites (Schubeler et al. 2001). Interestingly, promoter hypersensitivity and transcription can be segregated at the $\beta$-globin promoter by examining differential activities of erythroid kruppellike factor (EKLF), which has functionally separate BRG1 (chromatin modifying) interaction and transactivation domains (Brown et al. 2002). EKLF-mediated recruitment of BRG1 to the $\beta$-globin gene promoter through the BRG1 interaction domain results in hypersensitive site formation but only low-level transcription, while abundant transcription more typical of this gene additionally requires the transactivation domain. EKLF also appears to be involved in the formation of the LCR-gene complex (Drissen et al. 2004). All of these phenomena have been proposed to be required for efficient recruitment of the polymerase complex to the adult $\beta$-globin promoter; however, the data could be interpreted equally well as a circular argument in favor of the hypothesis that they increase affinity of the gene for a factory.

\section{Future resolution}

With the advent of this and other 21 st century investigations that address subnuclear localization and its relevance to control over gene expression come a host of important and unanswered mechanistic questions. First, it is not yet clear whether transcription factories exist as such by themselves, in which case an enhancer may simply increase the affinity for (i.e., frequency of interaction with) factories, or whether factories preferentially nucleate on the enhancers of all expressed loci in a given cell type, in which alternative case the enhancer might function by increasing the ability of a locus to nucleate an active factory. Second, what is the dynamic and which are the molecules that seemingly draw inward the transcriptional net of factories, enhancers, and promoters as an erythroid cell matures? Are the confocal sections that we see through the light microscope reflecting increasing spatial/temporal constraints on chromatin, on the nuclear envelope, or on both (i.e., are active, energy-requiring physical processes within the nucleus, dictating

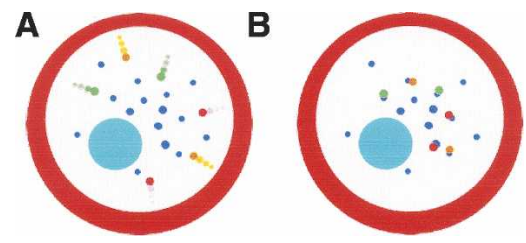

Figure 2. Possible models to explain the relocation of the $\beta$-globin genes in stage 4 erythroid cells. (A) $\beta$-Globin and other coexpressed genes migrate to the nuclear interior in pursuit of the increasingly scarce transcriptional machinery, which has been redistributed to the nuclear interior. $(B) \beta$-Globin and other coexpressed genes have specific cis elements that direct their migration to the nuclear interior where transcription factories form on them and their regulatory elements. 
that transcription can only take place in "open" subcompartments) (Verschure et al. 1999; Cremer et al. 2000), or is the three-dimensional factory "net" that we visualize in these images (e.g., Fig. 5 in Ragoczy et al. 2006) simply reflecting the fact that we can see only what we look for, and that the underlying mechanisms are controlled by cryptic molecules whose identity has not yet been revealed? In other words, are there subnuclear machines that actively constrain the transcriptional apparatus to an ever more refined organization as an erythroid cell differentiates, or is the entire process controlled purely by occupancy of the transcriptional apparatus into whatever nuclear space remains that happens not to be occupied by (hetero)chromatin? Resolution of thorny "chicken and egg" issues like these will require not only the discovery of new molecules that play key roles in defining and elaborating the process, but will likely also require the development of novel imaging applications. Given the progress in this emerging discipline over the past 5 years, we should expect answers sooner rather than later to many of these most basic questions about nuclear architecture and its active versus passive roles in directing transcription.

\section{References}

Andrulis, E.D., Neiman, A.M., Zappulla, D.C., and Sternglanz, R. 1998. Perinuclear localization of chromatin facilitates transcriptional silencing. Nature 394: 592-595.

Bender, M.A., Bulger, M., Close, J., and Groudine, M. 2000. $\beta$-Globin gene switching and DNase I sensitivity of the endogenous $\beta$-globin locus in mice do not require the locus control region. Mol. Cell 5: 387-393.

Brown, K.E., Guest, S.S., Smale, S.T., Hahm, K., Merkenschlager, M., and Fisher, A.G. 1997. Association of transcriptionally silent genes with Ikaros complexes at centromeric heterochromatin. Cell 91: 845-854.

Brown, K.E., Baxter, J., Graf, D., Merkenschlager, M., and Fisher, A.G. 1999. Dynamic repositioning of genes in the nucleus of lymphocytes preparing for cell division. Mol. Cell 3: 207217.

Brown, R.C., Pattison, S., van Ree, J., Coghill, E., Perkins, A., Jane, S.M., and Cunningham, J.M. 2002. Distinct domains of erythroid Kruppel-like factor modulate chromatin remodeling and transactivation at the endogenous $\beta$-globin gene promoter. Mol. Cell. Biol. 22: 161-170.

Bulger, M. and Groudine, M. 1999. Looping versus linking: Toward a model for long-distance gene activation. Genes \& Dev. 13: 2465-2477.

Carter, D., Chakalova, L., Osborne, C.S., Dai, Y.F., and Fraser, P. 2002. Long-range chromatin regulatory interactions in vivo. Nat. Genet. 32: 623-626.

Chakalova, L., Mitchell, J.A., Debrand, E., Osborne, C.S., and Fraser, P. 2005. Replication and transcription: Forces that shape the landscape of the genome. Nat. Rev. Genet. 6: 669677.

Chambeyron, S. and Bickmore, W.A. 2004. Chromatin decondensation and nuclear reorganization of the HoxB locus upon induction of transcription. Genes \& Dev. 18: 1119-1130.

Choi, O.R. and Engel, J.D. 1988. Developmental regulation of $\beta$-globin gene switching. Cell 55: 17-26.

Cremer, T. and Cremer, C. 2001. Chromosome territories, nuclear architecture and gene regulation in mammalian cells. Nat. Rev. Genet. 2: 292-301.
Cremer, T., Kreth, G., Koester, H., Fink, R.H., Heintzmann, R., Cremer, M., Solovei, I., Zink, D., and Cremer, C. 2000. Chromosome territories, interchromatin domain compartment, and nuclear matrix: An integrated view of the functional nuclear architecture. Crit. Rev. Eukaryot. Gene Expr. 10: 179-212.

Drissen, R., Palstra, R.J., Gillemans, N., Splinter, E., Grosveld, F., Philipsen, S., and de Laat, W. 2004. The active spatial organization of the $\beta$-globin locus requires the transcription factor EKLF. Genes \& Dev. 18: 2485-2490.

Enver, T., Raich, N., Ebens, A.J., Papayannopoulou, T., Costantini, F., and Stamatoyannopoulos, G. 1990. Developmental regulation of human fetal-to-adult globin gene switching in transgenic mice. Nature 344: 309-313.

Francastel, C., Walters, M.C., Groudine, M., and Martin, D.I. 1999. A functional enhancer suppresses silencing of a transgene and prevents its localization close to centrometric heterochromatin. Cell 99: 259-269.

Grande, M.A., van der Kraan, I., de Jong, L., and van Driel, R. 1997. Nuclear distribution of transcription factors in relation to sites of transcription and RNA polymerase II. J. Cell Sci. 110: 1781-1791.

Gribnau, J., Diderich, K., Pruzina, S., Calzolari, R., and Fraser, P. 2000. Intergenic transcription and developmental remodeling of chromatin subdomains in the human $\beta$-globin locus. Mol. Cell 5: 377-386.

Grosveld, F., van Assendelft, G.B., Greaves, D.R., and Kollias, G. 1987. Position-independent, high-level expression of the human $\beta$-globin gene in transgenic mice. Cell 51: 975-985.

Hetzer, M., Walther, T.C., and Mattaj, I.W. 2005. Pushing the envelope: Structure, function, and dynamics of the nuclear periphery. Annu. Rev. Cell Dev. Biol. 21: 347-380.

Hewitt, S.L., High, F.A., Reiner, S.L., Fisher, A.G., and Merkenschlager, M. 2004. Nuclear repositioning marks the selective exclusion of lineage-inappropriate transcription factor loci during $\mathrm{T}$ helper cell differentiation. Eur. J. Immunol. 34: 3604-3613.

Iborra, F.J., Pombo, A., Jackson, D.A., and Cook, P.R. 1996. Active RNA polymerases are localized within discrete transcription 'factories' in human nuclei. J. Cell Sci. 109: 14271436.

Jackson, D.A. and Cook, P.R. 1985. Transcription occurs at a nucleoskeleton. EMBO I. 4: 919-925.

Jackson, D.A., Hassan, A.B., Errington, R.J., and Cook, P.R. 1993. Visualization of focal sites of transcription within human nuclei. $E M B O$ J. 12: 1059-1065.

Jackson, D.A., Iborra, F.J., Manders, E.M., and Cook, P.R. 1998. Numbers and organization of RNA polymerases, nascent transcripts, and transcription units in HeLa nuclei. Mol. Biol. Cell 9: 1523-1536.

Khandekar, M., Suzuki, N., Lewton, J., Yamamoto, M., and Engel, J.D. 2004. Multiple, distant Gata2 enhancers specify temporally and tissue-specific patterning in the developing urogenital system. Mol. Cell. Biol. 24: 10263-10276.

Kimura, H., Sugaya, K., and Cook, P.R. 2002. The transcription cycle of RNA polymerase II in living cells. J. Cell Biol. 159: 777-782.

Kosak, S.T., Skok, J.A., Medina, K.L., Riblet, R., Le Beau, M.M., Fisher, A.G., and Singh, H. 2002. Subnuclear compartmentalization of immunoglobulin loci during lymphocyte development. Science 296: 158-162.

Lettice, L.A., Horikoshi, T., Heaney, S.J., van Baren, M.J., van der Linde, H.C., Breedveld, G.J., Joosse, M., Akarsu, N., Oostra, B.A., Endo, N., et al. 2002. Disruption of a long-range cis-acting regulator for Shh causes preaxial polydactyly. Proc. Natl. Acad. Sci. 99: 7548-7553. 
Mahy, N.L., Perry, P.E., and Bickmore, W.A. 2002a. Gene density and transcription influence the localization of chromatin outside of chromosome territories detectable by FISH. J. Cell Biol. 159: 753-763.

Mahy, N.L., Perry, P.E., Gilchrist, S., Baldock, R.A., and Bickmore, W.A. 2002b. Spatial organization of active and inactive genes and noncoding DNA within chromosome territories. J. Cell Biol. 157: 579-589.

Martin, D.I., Fiering, S., and Groudine, M. 1996. Regulation of $\beta$-globin gene expression: Straightening out the locus. Curr. Opin. Genet. Dev. 6: 488-495.

Misteli, T. 2001. The concept of self-organization in cellular architecture. J. Cell Biol. 155: 181-185.

Osborne, C.S., Chakalova, L., Brown, K.E., Carter, D., Horton, A., Debrand, E., Goyenechea, B., Mitchell, J.A., Lopes, S., Reik, W., et al. 2004. Active genes dynamically colocalize to shared sites of ongoing transcription. Nat. Genet. 36: 10651071.

Ragoczy, T., Bender, M.A., Telling, A., Byron, R., and Groudine, M. 2006. The locus control region is required for association of the murine b-globin locus with engaged transcription factories during erythroid maturation. Genes \& Dev. (this issue).

Schubeler, D., Groudine, M., and Bender, M.A. 2001. The murine $\beta$-globin locus control region regulates the rate of transcription but not the hyperacetylation of histones at the active genes. Proc. Natl. Acad. Sci. 98: 11432-11437.

Tolhuis, B., Palstra, R.J., Splinter, E., Grosveld, F., and de Laat, W. 2002. Looping and interaction between hypersensitive sites in the active $\beta$-globin locus. Mol. Cell 10: 1453-1465.

Tuan, D., Kong, S., and Hu, K. 1992. Transcription of the hypersensitive site HS2 enhancer in erythroid cells. Proc. Natl. Acad. Sci. 89: 11219-11223.

Verschure, P.J., van Der Kraan, I., Manders, E.M., and van Driel, R. 1999. Spatial relationship between transcription sites and chromosome territories. J. Cell Biol. 147: 13-24.

Wansink, D.G., Schul, W., van der Kraan, I., van Steensel, B., van Driel, R., and de Jong, L. 1993. Fluorescent labeling of nascent RNA reveals transcription by RNA polymerase II in domains scattered throughout the nucleus. J. Cell Biol. 122: 283-293.

Wiigerde, M., Grosveld, F., and Fraser, P. 1995. Transcription complex stability and chromatin dynamics in vivo. Nature 377: 209-213. 


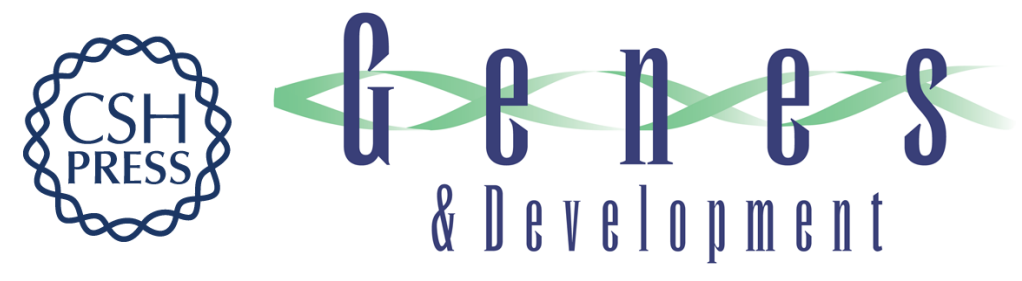

\section{Constricting restricted transcription: the (actively?) shrinking web}

Peter Fraser and James Douglas Engel

Genes Dev. 2006, 20:

Access the most recent version at doi:10.1101/gad.1438106
Related Content The locus control region is required for association of the murine ${ }^{2}$-globin locus with engaged transcription factories during erythroid maturation Tobias Ragoczy, M.A. Bender, Agnes Telling, et al.
Genes Dev. UNKNOWN , 2006 20: 1447-1457

References This article cites 39 articles, 18 of which can be accessed free at:

http://genesdev.cshlp.org/content/20/11/1379.full.html\#ref-list-1

Articles cited in:

http://genesdev.cshlp.org/content/20/11/1379.full.html\#related-urls

\section{License}

Email Alerting

Receive free email alerts when new articles cite this article - sign up in the box at the top

Service right corner of the article or click here.

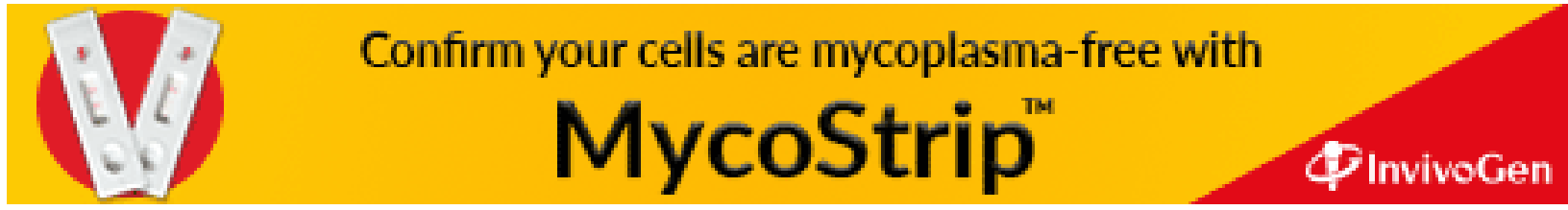

